\title{
A Report on Classical Cytogenetics of Hihgfin Barb Fish, Cyclocheilichthys armatus (Cypriniformes, Cyprinidae)
}

\author{
Patcharaporn Chaiyasan ${ }^{1}$, Weerayuth Supiwong ${ }^{2}$, Pasakorn Saenjundaeng ${ }^{2}$, \\ Kriengkrai Seetapan ${ }^{3}$, Sitthisak Pinmongkhonkul ${ }^{4}$ and Alongklod Tanomtong ${ }^{1 *}$ \\ ${ }^{1}$ Toxic Substance in Livestock and Aquatic Animals Research Group, Department of Biology, Faculty of Science, \\ Khon Kaen University, Muang, Khon Kaen 40002, Thailand \\ ${ }^{2}$ Faculty of Applied Science and Engineering, Khon Kaen University, Nong Khai Campus, Muang, Nong Khai \\ 43000, Thailand \\ ${ }^{3}$ School of Agriculture and Natural Resources, University of Phayao, Tumbol Maeka, Muang, Phayao 56000, \\ Thailand \\ ${ }^{4}$ Department of Biology, School of Science, University of Phayao, Tumbol Maeka, Muang, Phayao 56000, Thailand
}

Received October 12, 2017; accepted December 23, 2017

\begin{abstract}
Summary Conventional staining and Ag-NORs banding techniques were applied on the chromosomes of hihgfin barb fish, Cyclocheilichthys armatus. Specimens were collected from the Chao Phraya River, Thailand. The mitotic chromosome preparations were directly obtained from kidney tissues of eight males and eight females. The results revealed that the diploid chromosome numbers of $C$. armatus was $2 n=50$ and the fundamental number (NF) was 94 in both males and females. The karyotype consists of four large metacentric, six large submetacentric, two large acrocentric, eight medium metacentric, 12 medium submetacentric, 12 medium acrocentric and six medium telocentric chromosomes. No sex chromosome was observed. Ag-NORs indicating NORs were clearly exhibited at the region adjacent to telomere of the short arm of some chromosomes. The NORs located on chromosomes of the metacentric chromosome pair 3 and the submetacentric chromosome pair 7. The karyotype formula of $C$. armatus is $2 n=50=\mathrm{L}_{4}^{\mathrm{m}}+\mathrm{L}_{6}^{\mathrm{sm}}+\mathrm{L}_{2}^{\mathrm{a}}+\mathrm{M}_{8}^{\mathrm{m}}+\mathrm{M}_{12}^{\mathrm{sm}}+\mathrm{M}_{12}^{\mathrm{a}}+\mathrm{M}_{6}^{\mathrm{t}}$. Cytogenetic data of cyprinid fishes can be used as the basic knowledge for enhancing the existing cytotaxonomic information and chromosome evolution of the Cyprinidae especially in the genus Cyclocheilichthys.
\end{abstract}

Key words Hihgfin barb fish, Cyclocheilichthys armatus, Karyotype, NOR, Fundamental number, Chromosome.

Family Cyprinidae is the most abundant and globally widespread family of freshwater fish, comprising 3000, livings and extinct species in about 370 genera (Eschmeyer and Fong 2015). Hihgfin barb fish, C. armatus belongs to the family Cyprinidae. Hihgfin barb fish is wildly distributed in freshwater of Laos, Cambodia, Vietnam, Peninsular Malaysia and the Greater Sunda Islands of Borneo, Sumatra and Java, with additional recorded from the Philippines. In Thailand, it is found in the Mekong, Mae Klong and Chao Phraya Rivers as well as a host of smaller river basins, lakes and reservoirs. They feed on zooplankton, small crustaceans, chironomids and other insect larvae (Rainboth 1996). Cyclocheilichthys has eight species (Rainboth 1996). Although chromosome numbers of most species in the $C y$ clocheilichthys have been described (Magtoon and Arai 1989, 1993, Donsakul and Magtoon 1995, Donsakul and Poopitayasathaporn 2002, Donsakul et al. 2005, 2006, Seetapan 2007), there is no report for C. armatus. Chromosome analyses of Cyclocheilichthys species have shown the diploid chromosome number of $2 n=50$ (Table 1 ).

\footnotetext{
* Corresponding author, e-mail: tanomtong@hotmail.com DOI: $10.1508 /$ cytologia.83.149
}

The study on fish chromosomes has received considerable attention in recent years because of their importance in classification, evolution, heredity, systematic (Gold et al. 1990, Ueda et al. 2001, Barat et al. 2002, Barat and Sahoo 2007), fish breeding, rapid production of inbred lines and cytotaxonomy (Kirpichnikov 1981). Moreover, cytogenetic studies of fishes have been used as biological indicator for determination of water pollution (Klinkhardt 1993) and cytogenetic techniques have been widely applied to improve farmed stocks in many aquaculture species in the World (Beardmore et al. 2001, Desprez et al. 2003). An important characteristic of NORs in fish is related to that it has inter- and intraspecies polymorphism. NORs characterization can be a cytogenetic marker for cytotaxonomic studies and have been used for studying phylogenetic relationships between the Cyprinids (Amemiya and Gold 1988, Gatetti Jr. 1998, Almeida-Toledo et al. 2000).

As the mention above, a chromosome study in fishes is very important and clearly exhibits the benefits. Moreover, the karyological and NORs characteristics in the $C$. amatus were not reported. This research is the description of the $C$. amatus chromosomes from Thailand using conventional staining and Ag-NOR banding 
techniques.

\section{Materials and methods}

\section{Sample collection}

The $C$. armatus specimens (eight males and females) (Fig. 1) were obtained from the Chao Phraya River, Sing Buri province in the central part of Thailand. Species was identified morphologically using the keys and description of Rainboth (1996).

\section{Chromosome preparation}

Chromosomes were directly prepared in vivo as follows by Supiwong et al. $(2013,2017)$. The $0.05 \%$ colchicine ( $1 \mathrm{~mL}$ to $100 \mathrm{~g}$ body weight) was injected into the intramuscular or abdominal cavity of fish and left for $1 \mathrm{~h}$ before sacrificing. The kidney tissues were cut into small pieces then squashed, mixed with hypotonic solution $(0.075 \mathrm{M} \mathrm{KCl})$ and incubated for $30 \mathrm{~min}$. The samples were centrifuged at $1200 \mathrm{rpm}$ for $8 \mathrm{~min}$ and cells were fixed in fresh and cold Carnoy's fixative (3 methanol: 1 acetic acid) about 2-3 times. The fixation was repeated until the supernatant was clear and the pellet was mixed with $1 \mathrm{~mL}$ fixative. The mixture was dropped onto a clean and cold glass slide by micropipette followed by an air-drying technique.

\section{Chromosome staining}

Conventional staining was performed using 20\% Giemsa for $30 \mathrm{~min}$ (Rooney 2001). Ag-NOR banding was

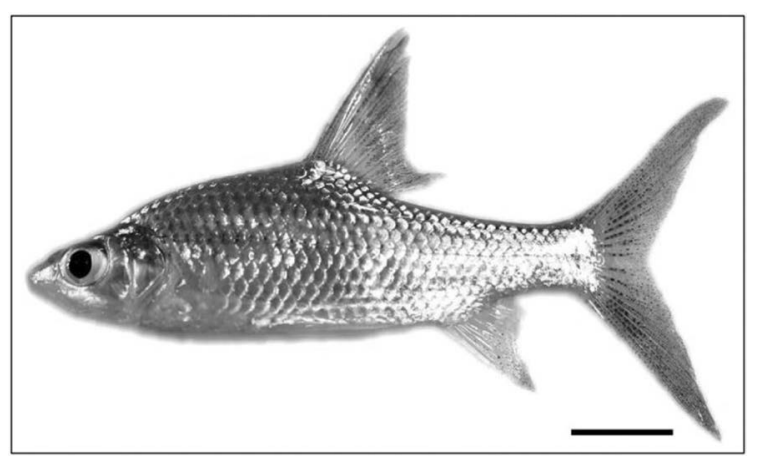

Fig. 1. General characteristics of hihgfin barb fish, Cyclocheilichthys armatus (Cypriniformes: Cyprinidae). Scale bar $=2 \mathrm{~cm}$. carried out by adding four drops of $50 \%$ silver nitrate and two drops of $2 \%$ gelatin on the glass slides (Howell and Black 1980). The glass slides were then sealed with cover slips and incubated at $60^{\circ} \mathrm{C}$ for $5 \mathrm{~min}$. After that they were soaked in distilled water until the cover slips were separated. The glass slides were stained with $20 \%$ Giemsa for $1 \mathrm{~min}$.

\section{Chromosomal checks, karyotyping and idiograming}

Chromosome counting was performed on mitotic metaphase cells under a microscope. Twenty clearly observable and well-spread metaphase cells from each male and female were selected and photographed. The length of short arm (Ls) and long arm (Ll) of each chromosome was measured and calculated for total chromosome length $(\mathrm{LT}=\mathrm{Ls}+\mathrm{Ll})$ to classify the sizes of chromosomes as large, medium and small. The relative length (RL) and the centromeric index (CI) were estimated. The CI was also computed to classify the types of chromosomes according to Turpin and Lejeune (1965). The centromeric index $(\mathrm{CI}, \mathrm{q} / \mathrm{p}+\mathrm{q})$ between $0.50-0.59$, $0.60-0.69,0.70-0.89$ and $0.90-0.99$ were described as metacentric, submetacentric, acrocentric and telocentric chromosomes, respectively. NF is obtained by assigning a value of two arms to metacentric, submetacentric and acrocentric chromosomes, and one arm to telocentric chromosome. All parameters were used in karyotyping and idiograming.

\section{Results and discussion}

\section{Diploid chromosome number, fundamental number and karyotype}

The diploid chromosome number of $C$. armatus was found as 50 (Figs. 2A, 3A). This result is consistent with previous reports in the Cyclocheilichthys (Magtoon and Arai 1989, 1993, Donsakul and Magtoon 1995, Donsakul and Poopitayasathaporn 2002, Donsakul et al. 2005, 2006, Seetapan 2007). These species have the chromosome diploid number of $2 n=50$, which is an apparent modal diploid number of the Cyclocheilichthys. Accordingly, it can be concluded that chromosome number in this genus is conserved as in other genera of the Barbinae subfamily (e.g., Acrossocheilus, Balantioehei-

Table 1. Cytogenetical data of the genus Cyclocheilichthys.

\begin{tabular}{|c|c|c|c|c|c|}
\hline Species & $2 n$ & $\mathrm{NF}$ & Karyotype formula & NOR & Reference \\
\hline C. amatus & 50 & 94 & $12 \mathrm{~m}+18 \mathrm{sm}+14 \mathrm{a}+6 \mathrm{t}$ & $\mathrm{S}(\mathrm{TR}) 4$ & Present study \\
\hline \multirow[t]{2}{*}{ C. apogon } & 50 & 70 & $12 \mathrm{~m}+8 \mathrm{sm}+6 \mathrm{a}+24 \mathrm{t}$ & - & Magtoon and Arai (1989) \\
\hline & 50 & 76 & $18 \mathrm{~m}+8 \mathrm{sm}+4 \mathrm{a}+20 \mathrm{t}$ & - & Donsakul and Poopitayasathaporn (2002) \\
\hline \multirow[t]{2}{*}{ C. enoplos } & 50 & 90 & $10 \mathrm{~m}+30 \mathrm{sm}+4 \mathrm{a}+6 \mathrm{t}$ & 4 & Magtoon and Arai (1993) \\
\hline & 50 & 72 & $14 \mathrm{~m}+8 \mathrm{sm}+10 \mathrm{a}+18 \mathrm{t}$ & - & Donsakul and Magtoon (1995) \\
\hline C. lagleri & 50 & 86 & $24 \mathrm{~m}+12 \mathrm{sm}+2 \mathrm{a}+12 \mathrm{t}$ & - & Donsakul et al. (2006) \\
\hline \multirow[t]{2}{*}{ C. repasson } & 50 & - & $8 m+10 s m+12 a+20 t$ & - & Seetapan (2007) \\
\hline & 50 & 78 & $12 \mathrm{~m}+16 \mathrm{sm}+6 \mathrm{a}+16 \mathrm{t}$ & - & Donsakul et al. (2005) \\
\hline
\end{tabular}

TR: telomeric region. - : no data. 


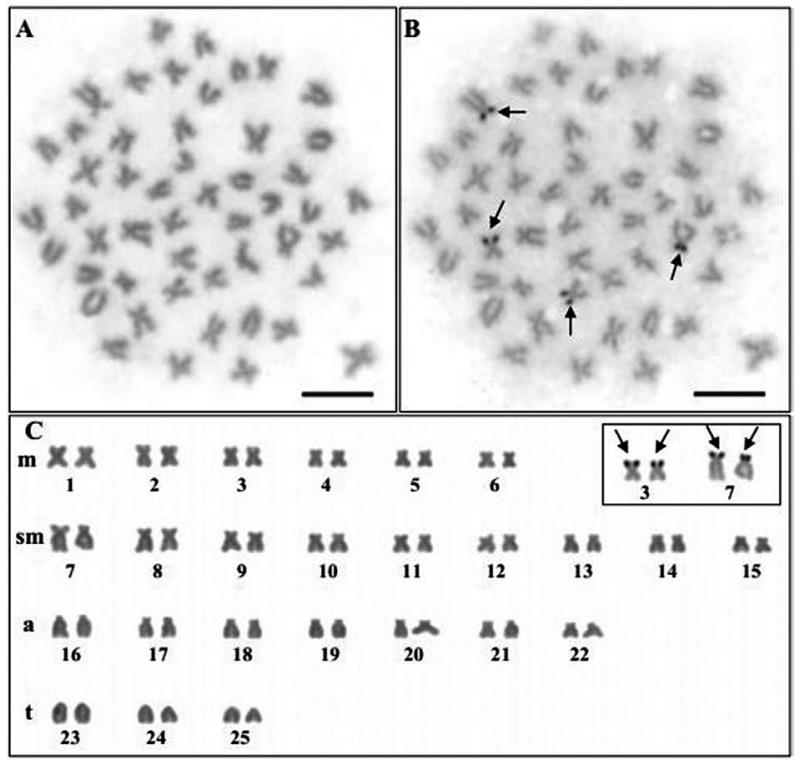

Fig. 2. Metaphase chromosome plates and karyotype of C. armatus (female) $2 n=50$ by conventional staining (A) and Ag-NOR banding techniques (B). (C) Karyotype arranged by chromosome shape, and chromosome pairs 3 and 7 having Ag-NOR (arrows). Scale bars $=5 \mu \mathrm{m}$.

los, Barbonymus, Catla, Poropuntius, and Puntius) (Arai 2011). The diploid chromosome number is rather a conservative characteristic which is used as an indicator of the closeness of species inter-relationships within families (Moyle and Cech 2004). The diploid number, $2 n=50$ would probably be the ancestral diploid number of the family because the characteristic that frequently occurs in a group can be considered as ancestral (Estabrook 1977).

The NF of $C$. armatus was 94 in both male and female. Although the NF in the genus Cyclocheilichthys varies from 70 to 90 (Magtoon and Arai 1989, 1993), $C$. armatus showed higher NF when compared with $C$. apogon, $C$. enoplos, $C$. lagleri and $C$. repasson from Thailand. It is considered that species with high NF is advanced state or apomorphic while one with low NF is a primitive state or plesiomorphic (Nirchio et al. 2002). The $C$. armatus karyotype consists of four large metacentric, six large submetacentric, two large acrocentric, eight medium metacentric, 12 medium submetacentric, 12 medium acrocentric and six medium telocentric chromosomes. The karyotype formula for this species is $2 n=50=\mathrm{L}_{4}^{\mathrm{m}}+\mathrm{L}_{6}^{\mathrm{sm}}+\mathrm{L}_{2}^{\mathrm{a}}+\mathrm{M}_{8}^{\mathrm{m}}+\mathrm{M}_{12}^{\mathrm{sm}}+\mathrm{M}_{12}^{\mathrm{a}}+\mathrm{M}_{6}^{\mathrm{t}}$. It is different from other Cyclocheilichthys species (Magtoon and Arai 1989, 1993). In view of this fact, the Cyclocheilichthys is similar in diploid chromosome number but there are different in NF and karyotypes. The NF and karyotypes might be the result from pericentric inversions of the telocentric chromosome which can be transformed to a new bi-arm chromosome. In addition, the NF values may be due to the variability of fish in this group (Galetti et al. 2000, Sukham et al. 2014). Moreover, the difference of the karyotypes probably dues to interspecific

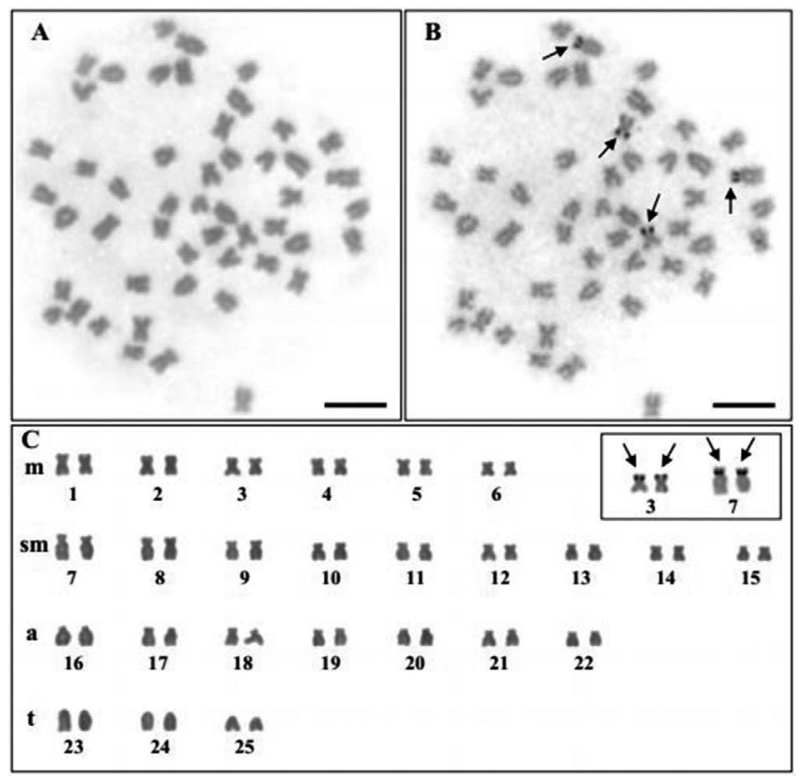

Fig. 3. Metaphase chromosome plates and karyotype of C. armatus (male) $2 n=50$ by conventional staining (A) and Ag-NOR banding techniques (B). (C) Karyotype arranged by chromosome shape and length and two chromosome pairs 3 and 7 with Ag-NOR (arrows). Scale bars $=5 \mu \mathrm{m}$.

variations and/or the use of different criteria for classification of chromosome types. The chromosomes characteristics of other Cyclocheilichthys species (C. apogon, C. enoplos, C. lagleri and C. repasson) have been only reported in Thailand. Thus, the chromosome evolution of this group is still incomplete savvy.

There is no evidence of sexual dimorphism of the chromosomes in this species which accord to the reports on C. apogon, C. enoplos, C. lagleri and C. repasson (Magtoon and Arai 1989, 1993, Donsakul et al. 2005, 2006, Seetapan 2007). Similar to several cyprinid fishes, no cytologically distinguishable sex chromosome was found (Ueda et al. 2006, Mani et al. 2009, Monteiro et al. 2009, Kaewmad et al. 2014, Sukham et al. 2014). It may be possible that sex chromosomes are at the initiation step of differentiation which cannot be detected by cytogenetic analyses (Na-Nakron 2000). However, there are the reports found sex chromosomes of the XY system (Chanda 1989, Karahan and Ergene 2009, 2010) and the ZW system (Barat 1985) in some species of Cyprinids.

\section{Chromosome markers}

The NOR is the location of $18 \mathrm{~S}$ and $28 \mathrm{~S}$ ribosomal RNA genes (rDNA) functioning to ribosome synthesis. The silver staining procedure is commonly used to visualize the activity of rDNA, since only functionally active genes at NORs of metaphase chromosomes are stained by silver (Galetti Jr. et al. 1984, Schmid et al. 2006). NORs are used as makers to indicate intra- and interspecific chromosome polymorphism in many groups of fishes (Ráb et al. 2008). This study was accomplished by 
Table 2. Mean length of short arm chromosome (Ls), long arm chromosome (L1), total arm chromosome (LT), relative length (RL) and centromeric index (CI) from 20 metaphases of male and female, hihgfin barb fish $(C$. armatus $) 2 n=50$.

\begin{tabular}{|c|c|c|c|c|c|c|c|}
\hline Chromosome pair & $\mathrm{Ls}(\mu \mathrm{m})$ & $\mathrm{Ll}(\mu \mathrm{m})$ & $\mathrm{LT}(\mu \mathrm{m})$ & RL \pm S.D. & $\mathrm{CI} \pm \mathrm{S} . \mathrm{D}$. & Chromosome size & Chromosome type \\
\hline 1 & 1.068 & 1.154 & 2.222 & $0.048 \pm 0.002$ & $0.519 \pm 0.009$ & Large & Metacentric \\
\hline 2 & 0.997 & 1.080 & 2.076 & $0.045 \pm 0.002$ & $0.520 \pm 0.011$ & Large & Metacentric \\
\hline $3 *$ & 0.924 & 1.013 & 1.936 & $0.042 \pm 0.002$ & $0.523 \pm 0.011$ & Medium & Metacentric \\
\hline 4 & 0.870 & 0.978 & 1.848 & $0.040 \pm 0.002$ & $0.529 \pm 0.017$ & Medium & Metacentric \\
\hline 5 & 0.832 & 0.938 & 1.770 & $0.038 \pm 0.002$ & $0.530 \pm 0.016$ & Medium & Metacentric \\
\hline 6 & 0.773 & 0.872 & 1.644 & $0.035 \pm 0.002$ & $0.530 \pm 0.016$ & Medium & Metacentric \\
\hline $7 *$ & 0.902 & 1.664 & 2.566 & $0.055 \pm 0.003$ & $0.648 \pm 0.023$ & Large & Submetacentric \\
\hline 8 & 0.844 & 1.487 & 2.330 & $0.050 \pm 0.002$ & $0.638 \pm 0.022$ & Large & Submetacentric \\
\hline 9 & 0.803 & 1.325 & 2.128 & $0.046 \pm 0.002$ & $0.622 \pm 0.018$ & Large & Submetacentric \\
\hline 10 & 0.738 & 1.241 & 1.979 & $0.043 \pm 0.002$ & $0.627 \pm 0.014$ & Medium & Submetacentric \\
\hline 11 & 0.710 & 1.167 & 1.877 & $0.041 \pm 0.002$ & $0.621 \pm 0.022$ & Medium & Submetacentric \\
\hline 12 & 0.698 & 1.119 & 1.817 & $0.039 \pm 0.001$ & $0.616 \pm 0.021$ & Medium & Submetacentric \\
\hline 13 & 0.661 & 1.099 & 1.760 & $0.038 \pm 0.002$ & $0.625 \pm 0.019$ & Medium & Submetacentric \\
\hline 14 & 0.640 & 1.041 & 1.681 & $0.036 \pm 0.002$ & $0.619 \pm 0.016$ & Medium & Submetacentric \\
\hline 15 & 0.616 & 0.980 & 1.596 & $0.034 \pm 0.001$ & $0.614 \pm 0.022$ & Medium & Submetacentric \\
\hline 16 & 0.468 & 1.651 & 2.119 & $0.046 \pm 0.003$ & $0.778 \pm 0.025$ & Large & Acrocentric \\
\hline 17 & 0.461 & 1.470 & 1.930 & $0.042 \pm 0.003$ & $0.762 \pm 0.030$ & Medium & Acrocentric \\
\hline 18 & 0.469 & 1.308 & 1.776 & $0.038 \pm 0.002$ & $0.737 \pm 0.025$ & Medium & Acrocentric \\
\hline 19 & 0.469 & 1.233 & 1.702 & $0.037 \pm 0.002$ & $0.724 \pm 0.023$ & Medium & Acrocentric \\
\hline 20 & 0.445 & 1.190 & 1.635 & $0.035 \pm 0.001$ & $0.728 \pm 0.023$ & Medium & Acrocentric \\
\hline 21 & 0.413 & 1.129 & 1.542 & $0.033 \pm 0.002$ & $0.733 \pm 0.027$ & Medium & Acrocentric \\
\hline 22 & 0.396 & 1.060 & 1.456 & $0.031 \pm 0.001$ & $0.728 \pm 0.020$ & Medium & Acrocentric \\
\hline 23 & 0.000 & 1.985 & 1.985 & $0.043 \pm 0.002$ & $1.000 \pm 0.000$ & Medium & Telocentric \\
\hline 24 & 0.000 & 1.749 & 1.749 & $0.038 \pm 0.003$ & $1.000 \pm 0.000$ & Medium & Telocentric \\
\hline 25 & 0.000 & 1.461 & 1.461 & $0.032 \pm 0.003$ & $1.000 \pm 0.000$ & Medium & Telocentric \\
\hline
\end{tabular}

* Chromosome having NOR.

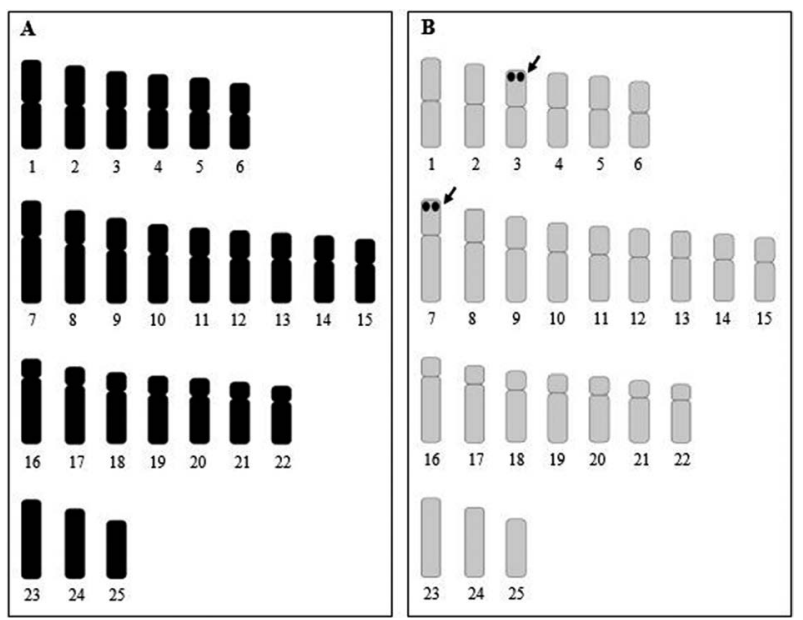

Fig. 4. Idiograms showing shape and length of chromosome of $C$. armatus represented the haploid set $(n=25)$ by conventional staining (A) and Ag-NOR staining (B). Arrows indicate NORs on the short arm of metacentric chromosome pair 3 and submetacentric chromosome pair 7 .

using Ag-NOR staining. The Ag-NORs were observed on near the telomeric regions of the short arms of the metacentric chromosome pair 3 and the submetacentric chromosome pair 7 in both male and female fishes (Figs. 2B, C and 3B, C). The result is consistent with previous reports of the $C$. enoplos which have two pair of Ag-NORs bearing chromosomes (Magtoon and Arai 1993). Most of the other species belonging to the family Cyprinidae have one pair chromosomes carrying of the NOR (Arai 2011). The occurrence of multiple NORs in fishes was considered to be apomorphic or derived condition whereas single pair of NORs was considered to be plesiomorphic or a primitive condition (Gold and Amemiya 1986).

The important chromosome marker of the C. armatus is the asymmetrical karyotype that was found for four types of chromosomes regarding the centromere position. The idiogram shows a continuous length gradation of chromosomes. The largest and smallest chromosomes show approximately two-fold size differences. The marker chromosomes were the chromosome pair 7, which is the largest submetacentric and the chromosome pair 22, which is the smallest acrocentric. The data of the chromosome measurement on mitotic metaphase cells are shown in Table 2. Idiograms by conventional staining and Ag-NOR banding are shown in Fig. 4.

Furthermore, the information of chromosome morphology and the position as well as number of NORs in C. armatus suggested that these cytotaxonomic markers could be utilized in contribute toward clarifying the karyotypic evolution and phylogenetic relationships in this group. Further analysis, the additional species of Cyclocheilichthys of different regions and different staining techniques such as fluorescent staining with the CG specific chromomycin $\mathrm{A}_{3}$ and fluorescence in situ hybridization technique will be used to study for better understanding of the chromosome evolution in the group and confirming the apparent conservative nature of the diploid number in this cyprinid fish. 


\section{Acknowledgements}

This work was supported by Science Achievement Scholarship of Thailand (SAST) and the Toxic Substances in Livestock and Aquatic Animals Research Group, Khon Kaen University.

\section{References}

Almeida-Toledo, L. F., Foresti, F. and Toledo-Filho, S. A. 2000. Karyotypic evolution in neotropical freshwater fish. Chromosome Today 13: 169-181.

Amemiya, C. T. and Gold, J. R. 1988. Chromosomal NORs as taxonomic and systematic characters in North American cyprinid fishes. Genetica 76: 81-90.

Arai, R. 2011. Fish Karyotypes: A Check List. Springer, Tokyo.

Barat, A. 1985. A Study of Chromosomes in Some Indian Teleost (Pisces). Ph.D. Thesis. Kalyani University, West Bengal.

Barat, A. and Sahoo, P. K. 2007. Karyotype analysis of Channa punctatus (Pisces) using restriction endonucleases. Cytologia 72: 471-473.

Barat, A., Sahoo, P. K. and Ponniah, A. G. 2002. Karyotype and Nucleolar Organizer Regions (NORs) in a Few Hill Stream Fishes. In: Ayyappan, S., Jena, J. K. and Joseph, M. M. (eds.). The Fifth Indian Fisheries Forum Proceedings, AFSIB, Mangalore and AoA, Bhubaneswar. pp. 111-114.

Beardmore, J. A., Mair, G. C. and Lewis, R. I. 2001. Monosex male production in finfish as exemplified by tilapia: Applications, problems, and prospects. Aquaculture 197: 283-301.

Chanda, T. 1989. A study of Chromosome in Some Hill Stream Fishes of Assam India. Ph.D. thesis. Kalyani University, West Bengal.

Desprez, D., Mélard, C., Hoareau, M. C., Bellemène, Y., Bosc, P. and Baroiller, J. F. 2003. Inheritance of sex in two ZZ pseudofemale lines of tilapia, Oreochromis aureus. Aquaculture 218: 131-140.

Donsakul, T. and Magtoon, W. 1995. Karyological studies of Puntius brevis (Bleeker, 1850) and Cyclocheilichthys enoplos in Thailand. In: Proceeding of 21st Congress on Science and Technology of Thailand, BO 14. pp. 292-293. (in Thai)

Donsakul, T., Magtoon, W. and Rangsiruji, A. 2005. Karyotypes of four cyprinid fishes: Cyclocheilichthys repasson, Cosmochilus harmandi, Poropuntius deauratus and Sikukia gudgeri from Thailand. In: Proceedings of 43rd Kasetsart University Annual Conference, Kasetsart University, Bangkok. pp. 344-351. (in Thai)

Donsakul, T., Magtoon, W. and Rangsiruji, A. 2006. Karyological studies of four Cyprinid Fishes: Barbichthys nitidus, Mystacoleucus argenteus, Cychocheilichthys lagleri and Systomus sp. from Thailand. In: Proceedings of the 44th Kasetsart University Annual Conference, Kasetsart University, Bangkok. pp. 469-476. (in Thai)

Donsakul, T. and Poopitayasathaporn, A. 2002. Karyotype of Fifteen Species of Cyprinid Fishes (Family Cyprinidae) from Thailand. Srinakharinwirot University, Bangkok. (in Thai)

Estabrook, G. F. 1977. Does common equal primitive? Syst. Bot. 2: 36-42.

Eschmeyer, W. N. and Fong, J. D. 2015. The Catalog of Fishes. Institute for Biodiversity Science and Sustainability. Academy of Sciences, California.

Galetti, P. M. Jr. 1998. Chromosome diversity in neotropical fish: NOR studies. Ital. J. Zool. 65 sup1: 53-56.

Galetti, P. M., Aguilar, C. T. and Molina, W. F. 2000. An overview of marine fish cytogenetics. Mar. Genet. 420: 55-62.

Galetti, P. M. Jr., Foresti, F., Bertollo, L. A. C. and Moreira, O. 1984. Characterization of eight species of Anostomidae (Cypriniformes) fish on the basis of the nucleolar organizing region.
Caryologia 37: 401-406.

Gold, J. R. and Amemiya, C. T. 1986. Cytogenetic studies in North American minnows (Cyprinidae) XII. Pattern of chromosomal nucleolus organizer region variation among 14 species. Can. J. Zool. 65: 1869-1877.

Gold, J. R., Li, Y. C., Shipley, N. S. and Powers, P. K. 1990. Improved methods for working with fish chromosomes with a review of metaphase chromosome banding. J. Fish Biol. 37: 563-575.

Howell, W. M. and Black, D. A. 1980. Controlled silver-staining of nucleolus organizer regions with a protective colloidal developer: a 1-step method. Experientia 36: 1014-1015.

Kaewmad, P., Monthatong, M., Supiwong, W., Saowakoon, S. and Tanomtong, A. 2014. Natural autotetraploid and chromosomal characteristics in the subfamily Botiinae (Cypriniformes, Cobitinae) from northeast Thailand. Cytologia 79: 299-313.

Karahan, A. and Ergene, S. 2009. Cytogenetic variation of geographically isolated four populations of Garra rufa [(Heckel, 1843) (Pisces, Cyprinidae)] in Turkey. Caryologia 62: 276-287.

Karahan, A. and Ergene, S. 2010. Cytogenetic analysis of Garra variabilis (Heckel, 1843) (Pisces, Cyprinidae) from Savur Stream (Mardin), Turkey. Turk. J. Fish Aquat. Sci. 10: 483-489.

Kirpichnikov, V. S. 1981. Genetic Bases of Fish Selection. Springer Verlag, New York.

Klinkhardt, M. 1993. Fish Chromosomes as Sensitive Toxicity Indicators-Possibilities and Limits. In: Braunbeck, T. H., Hanke, W. and Segner, S. (eds.). Fish in Ecotoxicology and Ecophysiology. Proceedings of an International Symposium, Heidelberg. pp. 45-54.

Magtoon, W. and Arai, R. 1989. Karyotypes of five Puntius species and one Cyclocheilichthys species (Pisces, Cyprinidae) from Thailand. Bull. Natl. Mus. Nat. Sci. Ser. A 15: 167-175.

Magtoon, W. and Arai, R. 1993. Karyotypes and distribution of nucleolus organizer regions in cyprinid fishes from Thailand. Jpn. J. Ichthyol. 40: 77-85.

Mani, I., Kumar, R., Singh, M., Kushwaha, B., Nagpure, N. S., Srivastava, P. K., Murmu, K., Rao, D. S. K. and Lakra, W. S. 2009. Karyotypic diversity and evolution of seven mahseer species (Cyprinidae) from India. J. Fish Biol. 75: 1079-1091.

Monteiro, R., Carvalho, C. and Collares-Pereira, M. J. 2009. Karyotype and genome size of Iberochondrostoma almacai (Teleostei, Cyprinidae) and comparison with the sister-species $I$. lusitanicum. Genet. Mol. Biol. 32: 268-275.

Moyle, P. B. and Cech, J. J. 2004. Fishes. An Introduction to Ichthyology. Prentice Hall, Upper Saddle River.

Na-Nakron, U. 2000. Fish Genetics. Kasetsart University Press, Bangkok.

Nirchio, M., Turner, B. J., Perez, J. E., Gaviria, J. I. and Cequea, H. 2002. Karyotypes of three species of toadfish (Batrachoididae: Teleostei) from Venezuela. Sci. Mar. 66: 1-4.

Ráb, P., Rábová, M., Pereira, C. S., Collares-Pereira, M. J. and Pelikánová, Š. 2008. Chromosome studies of European cyprinid fishes: Interspecific homology of leuciscine cytotaxonomic marker-the largest subtelocentric chromosome pair as revealed by crossspecies painting. Chromosome Res. 16: 863-873.

Rainboth, W. J. 1996. FAO Species Identifcation Field Guide for Fisheries Purposes. Fishes of the Cambodian Mekong. FAO, Rome.

Rooney, D. E. 2001. Human Cytogenetics: Constitutional Analysis, a Practical Approach. Oxford University Press, London.

Schmid, M., Ziegler, C. G., Steinlein, C., Nanda, I. and Schartl, M. 2006. Cytogenetics of the bleak (Alburnus alburnus), with special emphasis on the B chromosomes. Chromosome Res. 14: 231-242.

Seetapan, K. 2007. Karyotypes of sex fish species of the family Cyprinidae. In: Proceedings of the 45th Kasetsart University Annual Conference. Kasetsart University, Bangkok. pp. 749-758. (in Thai) 
Sukham, S., Chingakham, B., Thoidingjam, L., Waikhom, G., Kumar, R. and Kushwaha, B. 2014. A cytogenetical study on Barilius ngawa, Vishwanath and Manojkumar, 2002 (Cypriniformes: Cyprinidae) from Northeast India, Manipur. Int. J. Fish. Aquac. 4: 58-62.

Supiwong, W., Boonsuk, J., Jantarat, S., Suvarnaraksha, A., Pengseng, P. and Tanomtong, A. 2017. The first chromosomal characteristics of nucleolar organizer regions and karyological analysis of two chaetodontid fishes (Perciformes, Chaetodontidae). Cytologia 82: 33-39.

Supiwong, W., Tanomtong, A., Chaveerach, A., Tanee, T., Khak- hong, S. and Sanoamuang, L. 2013. Interpopulational variation of NOR positions and karyotypic analysis of Siamese catfish (Pseudomystus siamensis) in Thailand. Cytologia 78: 25-34.

Turpin, R. and Lejeune, J. 1965. Les Chromosomes Humains. Gauthier-Pillars, Paris.

Ueda, T., Iijima, K., Naoi, H., Arai, R., Ishinabe, T. and Jeon, S. R. 2006. Karyotypes of three Tanakia bitterlings (Pisces, Cyprinidae) from East Asia. Cytologia 71: 251-255.

Ueda, T., Naoi, H. and Arai, R. 2001. Flexibility on the karyotype evolution in bitterlings (Pisces, Cyprinidae). Genetica 111: 423-432. 